\title{
Cadmium-binding polypeptides in microalgal strains with laboratory-induced cadmium tolerance
}

\author{
Gary H. Wikfors ${ }^{1}$, Amit Neeman ${ }^{2}$, Paul J. Jackson ${ }^{2}$ \\ ${ }^{1}$ NOAA, National Marine Fisheries Service, Northeast Fisheries Science Center, Milford, Connecticut 06460, USA \\ ${ }^{2}$ Life Sciences Division, Genomics and Structural Biology Group, Los Alamos National Laboratory, Los Alamos, \\ New Mexico 87545, USA
}

\begin{abstract}
Strains of 5 algal species that have been induced to develop tolerance to previously toxic cadmium (Cd) concentrations were investigated for production of the Cd-binding polypeptides, poly $(\gamma$ glutamylcysteinyl)glycines, $(\gamma-\mathrm{EC})_{n} \mathrm{G}$. Liquid chromatography using Sephadex G-50, ICP analysis of Cd in chromatographic fractions, and amino acid analysis provided clear evidence of $(\gamma \text {-EC })_{n}$ G production in the 2 most tolerant species, Phaeodactylum tricornutum and Dunaliella tertiolecta. Production of Cdbinding peptide in $P$. tricornutum was positively correlated with cellular Cd content, on a dry-weight basis. In contrast, Cd-tolerant strains of Isochrysis galbana, Pavlova lutheri, and Tetraselmis maculata did not produce detectable $(\gamma-\mathrm{EC})_{n} \mathrm{G}$. Although Cd-tolerant $I$. galbana differed from the control strain in some aspects of polypeptide content, as seen by the production of thiol-rich compounds, the specific mechanism for enhanced $\mathrm{Cd}$ tolerance in the 3 species that do not produce $(\gamma-\mathrm{EC})_{n} \mathrm{G}$ remains unknown.
\end{abstract}

\section{INTRODUCTION}

Cadmium (Cd) has been identified as a 'priority pollutant' by the U.S. Environmental Protection Agency (US EPA 1979, Eisler 1985), at least in part because elevated concentrations have been found in fishery products intended for human consumption (Hall et al. 1976). This demonstrates that $\mathrm{Cd}$ does accumulate in marine biomass, despite the limited solubility of free $\mathrm{Cd}^{2+}$ in seawater (Eaton 1976, Sunda et al. 1978). One possible route by which $\mathrm{Cd}$ may enter the marine food web is through uptake by phytoplankton exposed to sub-lethal concentrations of this ion. The inhibitory effect of $\mathrm{Cd}$ upon microalgae has been documented in culture experiments (Jennings 1979, Rachlin et al. 1982, 1983, Wikfors \& Ukeles 1982, Fisher et al. 1984, Peterson \& Healey 1985) and studies of natural phytoplankton assemblages (Wolter et al. 1984, Frithsen et al. 1987). Interspecific differences in microalgal $\mathrm{Cd}$ tolerance were shown. Moreover, exceptionally tolerant strains of several algal species have been isolated from contaminated environments (Stokes et al. 1977. Murphy et al. 1982, Bariaud \& Maestre 1984) or selected experimentally in the laboratory ( $\mathrm{Li} \mathrm{1980,}$ Wikfors \& Ukeles 1982, Collard \& Matagne 1990).
Understanding of mechanisms by which some algae tolerate $\mathrm{Cd}$ has progressed only recently with the recognition of 'non-metallothionein binding proteins' (Stone \& Overnell 1985). Cysteine-rich polypeptides that form aggregates in the presence of $\mathrm{Cd}$ were first identified in yeast cells (Murasugi et al. 1981, Kondo et al. 1985) and later in higher plants (Grill et al. 1985, Robinson et al. 1987). Several names have been given to this class of molecules; they are most precisely called poly $(\gamma$-glutamylcysteinyl $)$ glycines, $(\gamma-E C)_{n} \mathrm{G}, \quad$ based upon the structure of repeating $\gamma$-glutamylcysteine dipeptides with a single terminal glycine (Robinson \& Jackson 1986). In plants, $(\gamma-E C)_{n} G$ have been shown conclusively to bind $\mathrm{Cd}$ and to be induced by exposure to this metal ion (Robinson et al. 1988, Delhaize et al. 1989). Involvement of $(\gamma-\mathrm{EC})_{n} \mathrm{G}$ in the mechanism of metal tolerance has also been demonstrated (Delhaize et al. 1989).

Evidence that microalgal Cd tolerance is achieved by a mechanism which includes binding of induced polypeptides to this metal ion was first obtained with Euglena gracilis (Gingrich et al. 1984, Weber et al. 1987, 1988). Recent research (reviewed by Robinson 1989) has shown that heavy metal-binding polypeptides produced by algal species from several classes are 
Table 1. Algal strains used in experiments

\begin{tabular}{|c|c|c|c|}
\hline Species & Strain designation & Medium & $\begin{array}{c}\text { Conc. Cd } \\
\qquad(\mu \mathrm{M})\end{array}$ \\
\hline Isochrysis galbana & $\begin{array}{l}\text { I. galbana } \\
\text { I. galbana Cd } 2.5\end{array}$ & $\begin{array}{l}\mathrm{ASP}_{2}{ }^{\mathrm{a}} \\
\mathrm{ASP}_{2}+2.5 \mathrm{mg} \% \mathrm{CdCl}_{2}\end{array}$ & 136 \\
\hline Pavlova lutheri & $\begin{array}{l}\text { P. Iutheri } \\
P \text {. lutheri Cd } 2.5\end{array}$ & $\begin{array}{l}\mathrm{ASP}_{2} \\
\mathrm{ASP}_{2}+2.5 \mathrm{mg} \% \mathrm{CdCl}_{2}\end{array}$ & 136 \\
\hline Phaeodactylum tricornutum & $\begin{array}{l}\text { P. tricornutum } \\
\text { P. tricornutum Cd } 5 \\
\text { P. tricornutum Cd } 10 \\
\text { P. tricornutum Cd } 20\end{array}$ & $\begin{array}{l}\mathrm{ASP}_{2} \\
\mathrm{ASP}_{2}+5 \mathrm{mg} \% \mathrm{CdCl}_{2} \\
\mathrm{ASP}_{2}+10 \mathrm{mg} \% \mathrm{CdCl}_{2} \\
\mathrm{ASP}_{2}+20 \mathrm{mg} \% \mathrm{CdCl}_{2}\end{array}$ & $\begin{array}{r}272 \\
544 \\
1088\end{array}$ \\
\hline Dunaliella tertiolecta & $\begin{array}{l}\text { D. tertiolecta } \\
\text { D. tertiolecta Cd } 10\end{array}$ & $\begin{array}{l}\mathrm{ASP}_{2} \\
\mathrm{ASP}_{2}+10 \mathrm{mg} \% \mathrm{CdCl}_{2}\end{array}$ & 544 \\
\hline Tetraselmis maculata & $\begin{array}{l}\text { T. maculata } \\
\text { T. maculata Cd } 5\end{array}$ & $\begin{array}{l}\mathrm{ASP}_{2} \\
\mathrm{ASP}_{2}+5 \mathrm{mg} \% \mathrm{CdCl}_{2}\end{array}$ & 272 \\
\hline
\end{tabular}

of the $(\gamma-\mathrm{EC})_{n} \mathrm{G}$ type; synthesis of $(\gamma-\mathrm{EC})_{n} \mathrm{G}$ is induced by $\mathrm{Zn}, \mathrm{Pb}, \mathrm{Ag}, \mathrm{Cu}$, and $\mathrm{Hg}$ in addition to $\mathrm{Cd}$ (Gekeler et al. 1988, Maita \& Kawaguchi 1989). In the present study, we looked for $(\gamma-E C)_{n} G$ in strains of 5 algal species that have been selected, through gradual concentration increases over several years in culture, for expression of tolerance to $\mathrm{Cd}$ concentrations that are lethal upon initial exposure of the parent strain (Wikfors \& Ukeles 1982).

\section{MATERIALS AND METHODS}

Algal culture and extraction. The following microalgal species were used (Table 1): Isochrysis galbana Parke, Pavlova lutheri (Droop) Green, Phaeodactylum tricornutum Bohlin, Dunaliella tertiolecta Lerche, and Tetraselmis maculata Butcher. Stock strains of these species have been maintained for many years in artificial seawater medium $\mathrm{ASP}_{2}$ (Provasoli et al. 1957). Previously, Cd-tolerant sub-strains were developed from the above isolates through slow adaptation in progressively higher $\mathrm{Cd}$ concentrations (Wikfors \& Ukeles 1982). Strain designations for the $\mathrm{Cd}$ tolerant strains reflect the $\mathrm{Cd}$ concentration, in $\mathrm{mg} \% \mathrm{CdCl}_{2}$, to which the strain has been adapted for over $10 \mathrm{yr} . \mathrm{Cd}$ molar concentrations are listed in Table 1.

Algae were cultured in $500 \mathrm{ml}$ Erlenmeyer and $2800 \mathrm{ml}$ Fernbach flasks containing 250 and $1200 \mathrm{ml}$ of medium, respectively. Flask cultures were incubated at $20^{\circ} \mathrm{C}$ with illumination at $300 \mu \mathrm{E} \mathrm{m} \mathrm{m}^{-2} \mathrm{~s}^{-1}$ from coolwhite fluorescent bulbs on a 12/12 h light/dark cycle. Cells were harvested for analysis after $28 \mathrm{~d}$ of growth.
Previous experience had shown that these strains were in a nitrogen-deficient stationary phase at this time. Evidence for this lies in the incorporation of all medium nitrogen into algal protein before Day 28, even though rates of growth were limited by another factor, perhaps carbon, after 14 to 21 d (Wikfors \& Ukeles 1982, Wikfors et al. unpubl.). Algal cells were removed from culture media and rinsed with isotonic $\mathrm{NaCl}$ by cold $\left(3^{\circ} \mathrm{C}\right)$ centrifugation at $1020 \times g$ for $15 \mathrm{~min}$. The pellet of algal cells was then resuspended in $10 \mathrm{ml}$ of a buffered solution (10 mM Tris- $\mathrm{HCl}, \mathrm{pH} 7.4,10 \mathrm{mM} \mathrm{KCl}$, $1.5 \mathrm{mM} \mathrm{MgCl}_{2}, 50 \mathrm{mM}$ 2-mercaptoethanol). A small volume of culture was retained for cell counting in an Improved Neubauer hemocytometer (Bright Line) ${ }^{*}$. Cells were homogenized with an ultrasonic cell disrupter, and insoluble material was removed by cold centrifugation at $1500 \times g$ for $30 \mathrm{~min}$. The supernatant was poured into polypropylene tubes and shipped on wet ice from Milford in Los Alamos.

Separation of Cd-binding components of cell extracts by gel-filtration. At Los Alamos, algal extracts were centrifuged at $15000 \times g$ for $10 \mathrm{~min}$ to remove insoluble material. The supernatant was collected and passed through a $2.5 \times 100 \mathrm{~cm}$ column containing Sephadex G-50 (fine) (LKB Biotechnology, Inc., Piscataway, NJ, USA) equilibrated against a solution containing $50 \mathrm{mM}$ Tris- $\mathrm{HCl}, \mathrm{pH} 7.8$. Fractions $(8 \mathrm{ml})$ were collected and analyzed for thiol content. Thiol-rich fractions were further analyzed for $\mathrm{Cd}$ content.

Detection of thiol-rich compounds. Thiol-rich compounds were detected by the method of Ellman (1959).

\footnotetext{
- Mention of trade names does not imply endorsement
} 
The solution to be tested was mixed with an equal volume of a solution containing $0.075 \mathrm{mM}$ dithionitrobenzoic acid and $50 \mathrm{mM} \mathrm{KH} \mathrm{KO}_{4}$ titrated to $\mathrm{pH} 7.6$ with $\mathrm{NaOH}$. Samples were allowed to develop for 5 min, and then the $\mathrm{OD}_{405}$ was measured with a Perkin Elmer, Model 553 UV/VIS Spectrophotometer.

Detection of Cd. Cd was detected with a PerkinElmer Model 5500 Inductively Coupled Plasma (ICP) Spectrophotometer calibrated with $\mathrm{Cd}$ in $50 \mathrm{mM}$ Tris$\mathrm{HCl}, \mathrm{pH}$ 8.0.

Purification of thiol-rich compounds by gel affinity chromatography. Fractions from the Sephadex column which contained both thiols and Cd were pooled and the volume reduced by ultrafiltration in an Amicon Model 202 ultrafiltration unit containing a YC05 filter (500 Da, molecular-weight exclusion filter, Amicon Corp., Danvers, MA, USA) under nitrogen. The concentrated samples were then loaded onto a cold $\left(4^{\circ} \mathrm{C}\right)$ $1 \mathrm{ml}$ thiopropyl Sepharose column (Sigma Chemical Co., St. Louis) equilibrated against a solution containing $50 \mathrm{mM}$ Tris- $\mathrm{HCl}, \mathrm{pH} 7.8$ (initial flow rate, $50 \mathrm{ml}^{-1} \mathrm{~h}$ ). Metal-binding polypeptides were retained by the column and $\mathrm{Cd}$ was released. The column was then washed first with $50 \mathrm{ml}$ of a solution containing $50 \mathrm{mM}$ Tris- $\mathrm{HCl}, \mathrm{pH} 8.0,1 \mathrm{M} \mathrm{NaCl}$, then with $50 \mathrm{ml}$ of $50 \mathrm{mM}$ Tris- $\mathrm{HCl}, \mathrm{pH}$ 8.0. Polypeptides were eluted from the column at a flow rate of $3 \mathrm{ml}^{-1} \mathrm{~h}$ with $50 \mathrm{mM}$ 2 -mercaptoethanol in $50 \mathrm{mM}$ Tris- $\mathrm{HCl}_{1} \mathrm{pH}$ 8.0. Samples were measured for thiol content after repeated dilution and concentration by ultrafiltration through a YC05 filter to remove 2-mercaptoethanol. Fractions containing thiol-rich molecules were pooled and their volume again reduced by ultrafiltration.

Determination of amino acid content of metal-binding complexes. Concentrations of thiol-rich compounds were determined by Ellman assay (Ellman 1959) using reduced glutathione as the standard. Aliquots containing 1 to $5 \mu \mathrm{g}$ of polypeptide were dried in an acid-cleaned test tube. $\mathrm{HCl}(200 \mu \mathrm{l})$ containing $0.5 \%(\mathrm{v} / \mathrm{v})$ phenol was added to the bottom of a va- cuum vial. The tube containing the polypeptides was placed in the vacuum vial and the vial was sealed under vacuum after being flushed with 3 alternate vacuum-nitrogen cycles. The polypeptides were hydrolyzed for $24 \mathrm{~h}$ at $116{ }^{\circ} \mathrm{C}$. The vial was then cooled, excess $\mathrm{HCl}$ was removed with tissue, and the sample was dried under vacuum. Twenty $\mu \mathrm{l}$ of derivatization reagent $[7: 1: 1: 1(\mathrm{v} / \mathrm{v})$ ethanol: triethylamine (TEA): water : phenylisothiocyanate (PITC)] was then added to the redried sample. Samples were capped and allowed to stand at $22^{\circ} \mathrm{C}$ for $20 \mathrm{~min}$ before being placed under vacuum for $1 \mathrm{~h}$ to remove the PITC and dry the sample. The dried sample was redissolved in $20 \mu \mathrm{l}$ methanol. HPLC analysis of hydrolyzed samples was accomplished by separation on a $15 \mathrm{~cm} \times 3.9 \mathrm{~mm}$ Pico-Tag amino acid analysis column (Waters Associates, Milford, MA, USA). Eluent A contained $0.14 \mathrm{M}$ sodium acetate, $0.5 \mathrm{ml}$ TEA, pH 6.4; Eluent B contained $60 \%$ acetonitrile in water. The linear gradient was $10 \% \mathrm{~B}$ to $53 \% \mathrm{~B}$ in $10 \mathrm{~min}$. Flow rate was $1.0 \mathrm{ml} \mathrm{min}^{-1}$. Amino acids were detected with a UV detector set at $254 \mathrm{~nm}$. The column was calibrated previously with a standard amino acid mix. The process was found to underestimate cysteine in the samples. Therefore, results were compared to those obtained for glutathione, $(\gamma-\mathrm{EC})_{1} \mathrm{G}$, and a correction factor for the amount of cysteine present was calculated, based upon values obtained for the amino acid content of this compound.

\section{RESULTS}

Initial screening for Cd-binding polypeptides was conducted with $250 \mathrm{ml}$ cultures of $5 \mathrm{Cd}$-tolerant algal strains. Final population densities and numbers of cells extracted are given in Table 2. In 2 algal strains, Phaeodactylum tricornutum Cd 20 and Dunaliella tertiolecta $\mathrm{Cd} 10$, a thiol-rich peak similar in size to metalbinding complexes containing $(\gamma-\mathrm{EC})_{n} \mathrm{G}$ in higher plants was considered the first presumptive evidence of

Table 2. Screening of Cd-tolerant algal strains for metal-binding polypeptides

\begin{tabular}{|c|c|c|c|c|c|c|}
\hline $\begin{array}{l}\text { Strain } \\
\text { designation }\end{array}$ & $\begin{array}{l}\text { Cells ml } \mathrm{ml}^{-1} \\
\quad\left(\times 10^{6}\right)\end{array}$ & $\begin{array}{c}\text { Extracted } \\
\text { cells }\left(\times 10^{6}\right)\end{array}$ & $\begin{array}{l}\text { Thiol } \\
\text { peak }^{a}\end{array}$ & $\begin{array}{c}\mathrm{Cd} \\
(\mathrm{ppm})^{\mathrm{b}}\end{array}$ & $\begin{array}{c}\mathrm{Cu} \\
(\mathrm{ppm})\end{array}$ & $\begin{array}{c}\mathrm{Fe} \\
(\mathrm{ppm})\end{array}$ \\
\hline I. galbana Cd 2.5 & 3.65 & 730 & Broad, few thiols & 1.67 & 0.10 & 0.01 \\
\hline P. lutheri Cd 2.5 & 2.34 & 468 & Not present & 0.70 & 0.10 & 0.02 \\
\hline P. tricornutum Cd 20 & 5.09 & 1020 & Broad, thiol-rich & 36.34 & 0.09 & 0.04 \\
\hline D. tertiolecta Cd 10 & 1.74 & 348 & Broad, thiol-rich & 10.64 & 0.05 & 0.02 \\
\hline T. maculata Cd 5 & 0.39 & 78 & Not present & 0.24 & 0.03 & 0.01 \\
\hline Extraction buffer ${ }^{c}$ & - & - & - & 0.19 & 0.01 & $<0.01$ \\
\hline
\end{tabular}




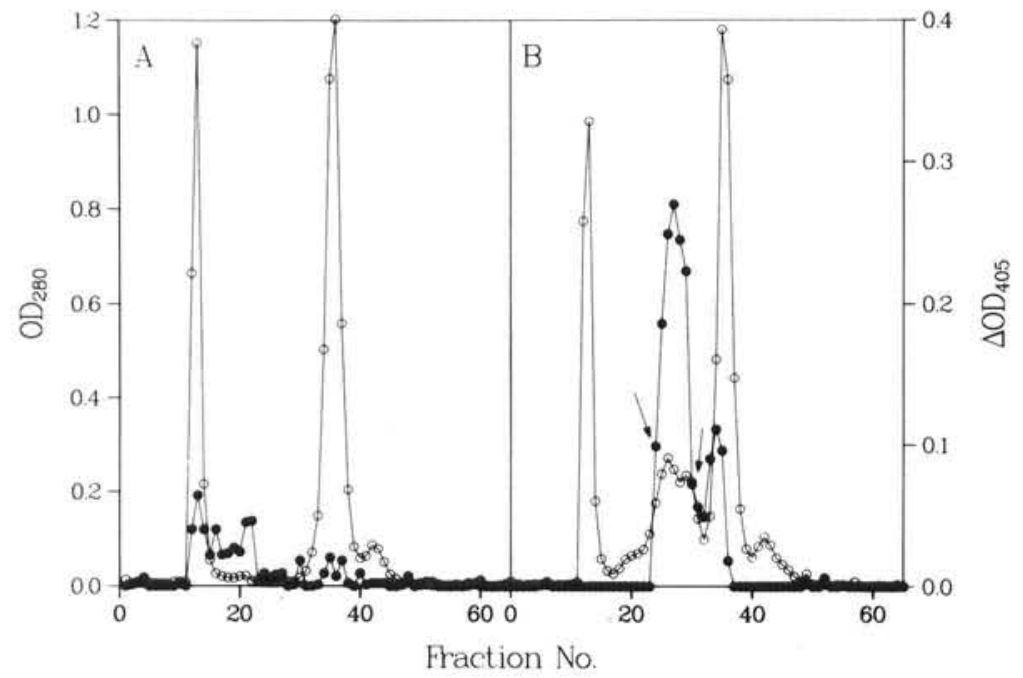

Fig. 1. Analysis of soluble portions of extracts from (A) Isochrysis galbana grown in media without additional Cd, and (B) I. galbana Cd 2.5 adapted to and cultured in $2.5 \mathrm{mg} \% \mathrm{CdCl}_{2}$. Separation was by passage through a Sephadex $\mathrm{G}-50$ (fine) gel filtration column. $\mathrm{OD}_{280}({ } \longrightarrow \mathrm{c})$ and change in absorbance at $405 \mathrm{~nm}$ after addition of Ellman's reagent $\left(\Delta \mathrm{OD}_{405 ;} \bullet \bullet\right)$ ) were measured for each fraction. Arrows in (B) mark limits of fractions collected for futher analysis metal-binding polypeptides in the samples. Isochrysis galbana $\mathrm{Cd} 2.5$ yielded a broad peak containing very low thiol concentrations, and the remaining 3 strains showed no evidence of thiol-rich compounds in the same size range ( 2 to $4 \mathrm{kD}$ ) (Table 2 ). ICP analysis of fractions in which Cd-binding polypeptides would be expected, revealed elevated $\mathrm{Cd}$ concentrations in $P$. tricornutum $\mathrm{Cd} 20$ and $D$. tertiolecta Cd 10; whereas assays for $\mathrm{Cd}$ gave uncertain results for I. galbana Cd 2.5. The remaining 3 strains showed no elevated $\mathrm{Cd}$ in the tested fractions. In no case was $\mathrm{Cu}$ or Fe elevated above background concentrations in fractions analyzed for these metal ions; this is the expected result because these metal ions are present in only traces in the growth medium (Table 2).

The presence of Cd-enriched thiol fractions in at least 2 algal strains provided the impetus for a more thorough analysis of these species to ascertain whether fractions did, in fact, contain $(\gamma \text {-EC })_{n} \mathrm{G}$ complexes. Fernbach-flask cultures provided sufficient biomass for these analyses. In Figs. 1 to 3, 2 measurements are plotted for Sephadex G-50 fractions of crude algal extracts: (1) optical density at $280 \mathrm{~nm}\left(\mathrm{OD}_{280}\right)$ for constitutive proteins, nucleic acids and other absorbing materials (peaks centered at ca 800 and 6000 d), and (2) the change in absorbance at $405 \mathrm{~nm}$ before and after addition of Ellman's reagent $\left(\Delta O D_{405}\right)$. It is clear from the presence of thiols (the change in $\mathrm{OD}_{405}$; Fig. 1) that tolerant Isochrysis galbana cells produced cysteinerich complexes in the presence of $\mathrm{Cd}$; control (Cd-free) cells produce no detectable cysteine-rich complexes. ICP analysis of pooled column fractions 25 to 30 from $I$. galbana Cd 2.5 extracts showed $\mathrm{Cd}$ concentrations almost 9-fold above background levels in these fractions. Dunaliella tertiolecta cultured in $10 \mathrm{mg} \% \mathrm{CdCl}_{2}$ yielded a thiol-rich peak smaller, relative to $\mathrm{OD}_{280}$ peaks, than I. galbana, and this peak was somewhat shifted to a higher apparent molecular weight. Fractions 16 to 24 (Fig. 2) were pooled for further analysis. $\mathrm{Cd}$ concentrations were 56-fold higher than background in these fractions. The most thorough analysis was conducted on Phaeodactylum tricornutum extracts because strains tolerant to 3 different concentrations of Cd were available; cells were also grown in media which did not contain this ion. Thiol-rich, $\Delta \mathrm{OD}_{405}$ peaks were found in extracts from 3 of the $4 P$. tricornutum strains. These peaks were centered uniformly at Fractions 27 to 28 (Fig. 3), and contained elevated Cd concentrations compared to background levels.

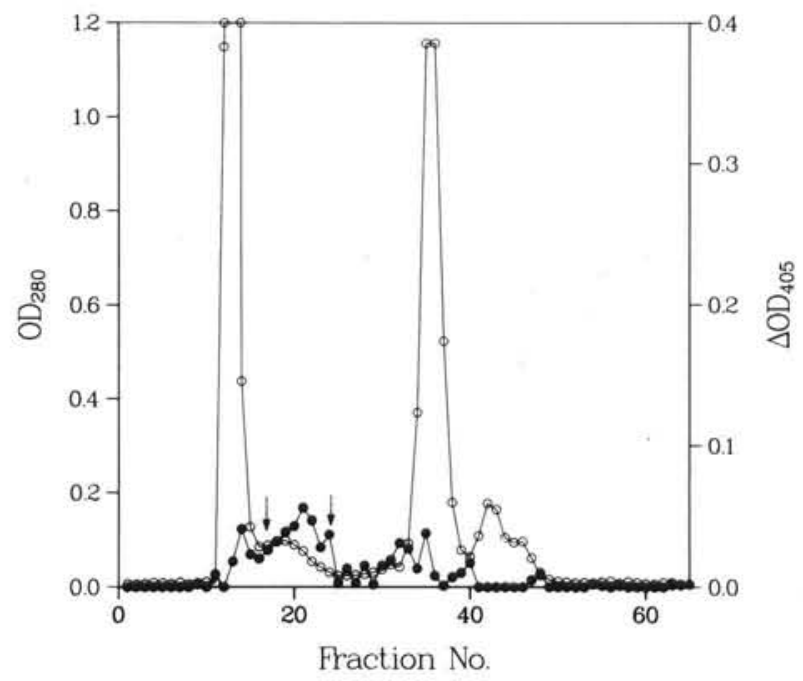

Fig. 2. Analysis of the soluble portion of an extract from Dunaliella tertiolecta (strain Cd 10) adapted to and cultured in $10 \mathrm{mg} \% \mathrm{CdCl}_{2}$. Separation was by passage of the extract through a Sephadex G-50 (fine) gel filtration column. Absorbance at $280 \mathrm{~nm}(\mathrm{OD} 280 ; \circ-0)$ and change in absorbance at $405 \mathrm{~nm}$ after addition of Ellman's reagent $\left(\Delta \mathrm{OD}_{405 ;} \bullet-\bullet\right)$ were measured for each fraction. Arrows mark the limits of fractions collected for content analysis 
Fig. 3. Analysis of soluble portions of extracts from (A) Phaaedactylum tricornutum grown in media with no added $\mathrm{Cd}$, and of $P$. tricornutum $\mathrm{Cd} \mathrm{5,10}$ and 20 growing in 5, 10 and $20 \mathrm{mg} \%$ $\mathrm{CdCl}_{2}$ (B to D respectively). Separation was by passage through a Sephadex G-50 (fine) gel filtration column. $\mathrm{OD}_{280}(\propto-0)$ and change in absorbance at $405 \mathrm{~nm}$ after addition of Ellman's reagent $\left(\mathrm{DOD}_{405} ; \bullet \longrightarrow\right.$ ) were measured for each fraction. Arrows mark the limits of fractions collected for content analysis

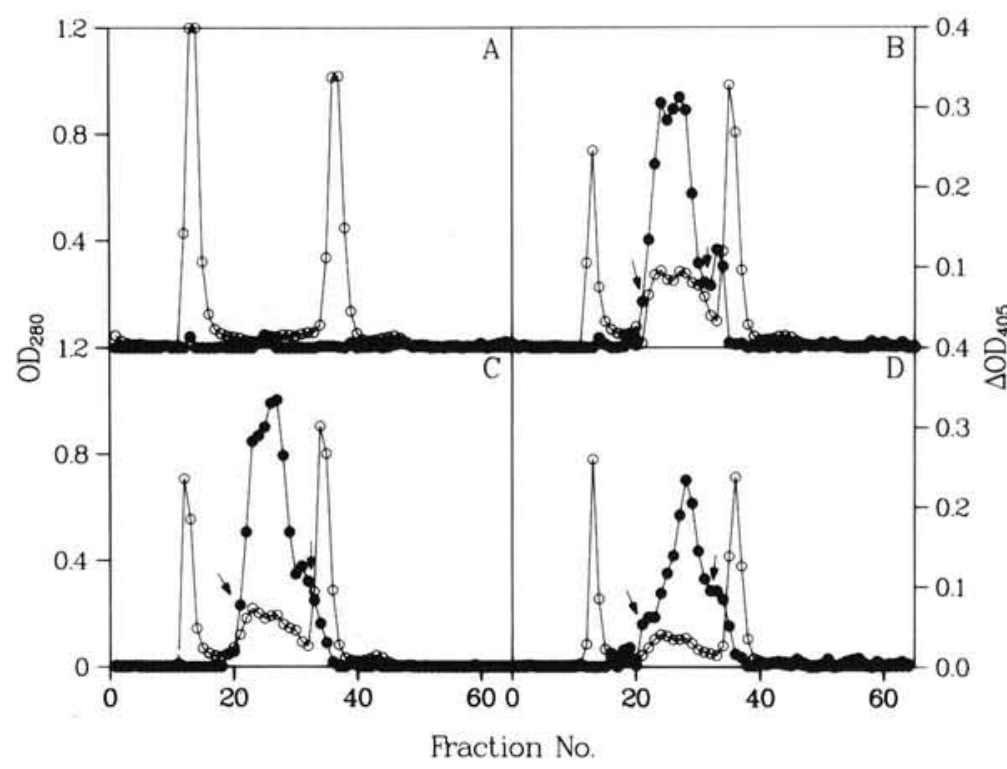

as a control; these extracts contain essentially all $(\gamma \text {-EC) })_{2} \mathrm{G}$ (Table 3).

\section{DISCUSSION}

The present study confirms a report of $(\gamma-E C)_{n} \mathrm{G}$ production in Phaeodactylum tricornutum grown in elevated Cd concentrations (Maita \& Kawaguchi 1989). Isolation of these metal-binding polypeptides from Dunaliella tertiolecta extends the list of microalgal taxa producing this class of Cd-binding compounds to the Polyblepharidaceae; other Chlorophycean taxa also possess this capacity (Gekeler et al. 1988). Because these species do produce Cd-binding polypeptides, insensitivity of these species to $\mathrm{Cd}$ toxicity upon initial exposure, relative to other microalgal species, may be

Table 3. Amino acid analyses of algal and control samples: analyses conducted on thiol-rich fractions separated by gel filtration through a Sephadex G-50 column. Values in nmol per $50 \mu \mathrm{l}$

\begin{tabular}{|c|c|c|c|c|c|}
\hline Sample & Glutamate & Cysteine & $\begin{array}{c}\text { Cysteine } \\
\text { (corrected }^{\mathrm{a}} \text { ) }\end{array}$ & Glycine & $\begin{array}{c}\text { Ratio }^{\mathrm{b}} \\
\text { Glu:Gys:Gly }\end{array}$ \\
\hline P. tricornutum Cd 5 & 0.3049 & 0.2495 & 0.6487 & 0.2712 & $1.12: 2.39: 1$ \\
\hline P. tricornutum $\mathrm{Cd} 10$ & 2.8686 & 1.0897 & 2.8330 & 1.1054 & $2.83: 2.78: 1$ \\
\hline P. tricornutum $\mathrm{Cd} 20$ & 2.5962 & 1.0545 & 2.7417 & 0.9514 & $2.73: 2.87: 1$ \\
\hline D. tertiolecta Cd 10 & 2.1888 & 0.9120 & 2.3712 & 0.9310 & $2.35: 2.55: 1$ \\
\hline I. galbana Cd 2.5 & 0.2500 & 0.2546 & 0.6620 & 0.1297 & $1.93: 5.12: 1$ \\
\hline D. innoxia ${ }^{c}$ & 1.2582 & 0.5093 & 1.3200 & 0.6873 & $1.83: 1.92: 1$ \\
\hline Glutathione & 1.8220 & 0.6996 & 1.8226 & 1.8430 & $0.99: 0.99: 1$ \\
\hline \multicolumn{6}{|c|}{$\begin{array}{l}\text { a Preparation of the polypeptides and glutathione resulted in an under-representation of cysteine in the assay. The above } \\
\text { values for glutathione, in which the ratio is known to be } 1: 1: 1 \text {, show this. Corrected cysteine values were obtained by } \\
\text { factoring in the } 0.99: 0.38 \text { under-analysis indicated by the glutathione results } \\
{ }^{\text {b }} \text { Ratios were calculated with corrected cysteine values } \\
{ }^{c} \text { Cell cultures grown in } 10 \mu \mathrm{M} \text { Fe and } 250 \mu \mathrm{M} \text { Cd (Fraction 1) }\end{array}$} \\
\hline
\end{tabular}


Table 4. Relationship between cellular Cd concentration and poly $(\gamma$-glutamylcysteinyl)glycine concentration in cadmiumtolerant algal strains. Values in $\mu$ g per $10^{6}$ cells

\begin{tabular}{|lcc|}
\hline Algal strain & Cd & $(\gamma \text {-EC })_{n} \mathrm{G}$ \\
\hline P. tricornutum Cd 5 & 0.204 & 0.84 \\
$P$. tricornutum Cd 10 & 0.558 & 5.86 \\
P. tricornutum Cd 20 & 0.987 & 8.16 \\
D. tertiolecta Cd 10 & 0.105 & 2.91 \\
I. galbana Cd 2.5 & 0.096 & Not present \\
\hline
\end{tabular}

attributed to a mechanism which includes the production of these polypeptides (Wikfors \& Ukeles 1982). Moreover, long exposure of these species to inhibitory, but sub-lethal $\mathrm{Cd}$ concentrations, may have selected for enhanced $(\gamma-\mathrm{EC})_{n} \mathrm{G}$ or glutathione biosynthesis, thereby permitting greater $\mathrm{Cd}$ tolerance. Robinson (1989) comments that this adaptive mechanism has not been demonstrated conclusively in the algae. However, he outlines 4 specific ways in which this may occur: '(1) Increased activity of enzymes involved in $(\gamma$ EC) ${ }_{n}$ G biosynthesis, (2) increased activity of enzymes responsible for $\mathrm{S}^{2-}$ saturation of metal- $(\gamma-\mathrm{EC})_{n} \mathrm{G}$ complexes, (3) modified compartmentation of one of the components, $(\gamma-\mathrm{EC})_{n} \mathrm{G}, \mathrm{S}^{2-}$, or metal, (4) modified rates of $(\gamma-\mathrm{EC})_{n} \mathrm{G}$ turnover.'

Evidence for Cd adaptation in Phaeodactylum tricornutum by selection for more robust activity of enzymes involved in $(\gamma-\mathrm{EC})_{n} \mathrm{G}$ metabolism can be found in the present study. During experimental development of Cdtolerant strains in this species, sub-cultures in intermediate $\mathrm{Cd}$ concentrations gave rise to progressively more tolerant populations (Wikfors \& Ukeles 1982). P. tricornutum $\mathrm{Cd} 10$ and $\mathrm{Cd} 20$ strains grow in concentrations that are acutely toxic to the original $P$. tricornutum strain from which they were derived, and both of these tolerant strains were shown in the present study to produce much $(\gamma-\mathrm{EC})_{n} \mathrm{G}$. According to this scenario, $P$. tricornutum 'constitutively' possesses the capacity to produce $(\gamma-\mathrm{EC})_{n} \mathrm{G}$ in response to elevated $\mathrm{Cd}$, but this response is insufficient in speed, magnitude or duration to permit survival at $\mathrm{Cd}$ concentrations greater than about $5 \mathrm{mg} \% \mathrm{CdCl}_{2}$. Production of large amounts of $\mathrm{Cd}$ binding polypeptide by strains adapted to higher $\mathrm{Cd}$ concentrations indicates that enzymic reactions must be somehow enhanced over levels achieved by nonadapted strains. Furthermore, the amount of Cd-binding polypeptide produced is approximately proportional to the concentration of metal tolerated - as well as being proportional to the weight-normalized $\mathrm{Cd}$ content of the cells (Table 4). This argues against mechanisms (3) and (4) of Robinson (1989). As enzyme rates were not measured in this study, the specific point in the biochemical pathway at which adaptation occurred, or whether or not tolerance is actually associated with the changes in the pathway, remains somewhat ambiguous, although part of the biochemical mechanism of Cd tolerance in this species is now known.

The likelihood that different algal species have different specific mechanisms for ameliorating toxic trace metal stress was also suggested by Robinson (1989). In Dunaliella tertiolecta, evidence is strong that Robinson's mechanism (3), modified compartmentation, is employed. In this case, perhaps extracellular dumping of the polypeptide-metal complex occurs. Dry weightspecific concentrations of both $\mathrm{Cd}$ and $(\gamma-\mathrm{EC})_{n} \mathrm{G}$ in $D$. tertiolecta Cd 10 are much lower than for Phaeodactylum tricornutum cultured in the same medium (Table 4). Previous studies suggesting that $D$. tertiolecta tolerates metal toxicants through some exclusion mechanism (Davies 1976, Fisher et al. 1984) do not address the question of whether metal ions are 'detoxified' within or outside of the cell. Our finding that $D$. tertiolecta synthesizes polypeptides with high affinity for $\mathrm{Cd}$ upon exposure to this ion renders less attractive the hypothesis that this species tolerates elevated $\mathrm{Cd}$ by simply resisting uptake. The presence of $(\gamma-\mathrm{EC})_{n} \mathrm{G}$ in medium that has supported population growth of $D$. tertiolecta Cd 10 will need to be established to confirm this hypothesis. More important, the question of the ultimate fate of polypeptide-metal complexes in plant cells (i.e. where do complexes go once formed) remains unanswered. Further work on $D$. tertiolecta may provide at least partial answers to some of these questions.

Perhaps more surprising than the identification of $(\gamma-\mathrm{EC})_{n} \mathrm{G}$ in Phaeodactylum tricornutum and Dunaliella tertiolecta is the apparent lack of evidence for the presence of these molecules in Cd-adapted strains of the other 3 species. Previous studies have not found any examples of microalgal strains which do not produce these molecules under $\mathrm{Cd}$ stress, and this mechanism has been suggested as a generalized plant response (Gekeler et al. 1988). However, it has also been determined that the ability to produce large quantities of these metal-binding polypeptides does not, in itself, confer metal tolerance upon plants (Jackson et al. 1989). The production of these polypeptides represents only part of the tolerance mechanism. It should be noted that the absence of evidence for the presence of these polypeptides in several algal strains does not preclude the presence of these metal-binding compounds under other conditions. Nevertheless, the sensitivities of the 3 strains not showing $(\gamma \text {-EC })_{n}$ G synthesis in our analyses, relative to $P$. tricornutum and $D$. tertiolecta both upon initial exposure (Wikfors \& Ukeles 1982) and after over $10 \mathrm{yr}$ of exposure, suggests that the mechanism which requires polypeptide synthesis may be disabled and/or supplanted by an alternate, less effective tolerance mechanism that limits $\mathrm{Cd}$ concentrations ultimately 
tolerated by some microalgae. In Isochrysis galbana and Pavlova lutheri, cellular exclusion of the metal apparently is not an effective tolerance mechanism because these species accumulate considerably more $\mathrm{Cd}$ on a dry weight-normalized basis than $D$. tertiolecta or $P$. tricornutum (Wikfors et al. unpubl.).

Isochrysis galbana is particularly intriguing. It is clear (Fig. 1) that extracts from the Cd-tolerant strain differ in cysteine content, compared to the control culture, although the ratio of glutamate: cysteine appears to preclude $(\gamma-\mathrm{EC})_{n} \mathrm{G}$ biosynthesis. Has it another cysteine-rich metal-binding polypeptide? Li (1980) found evidence of an inducible cytosolic moiety of ca $16 \mathrm{kD}$ that accumulated $\mathrm{Cd}$ as I. galbana cells grew in medium containing this ion, although immediate $\mathrm{Cd}$ binding appeared to occur in fractions with a molecular weight $<$ $3 \mathrm{kD}$. The cysteine-rich peak found in the current study may correspond to the latter fractions from Li's work. Furthermore, if our Cd-tolerant strain responded similarly to Li's, then the bulk of the Cd taken up by the cells would eventually be passed to a larger $16 \mathrm{kD}$ complex. To extend this hypothesis, our thiol-rich fractions and Li's $3 \mathrm{kD}$ material may both represent accumulation of certain amino acids as precursors or degradation products of unidentified metal-binding polypeptides. High cellular uptake of $\mathrm{Cd}$ by $I$. galbana that cannot be accounted for by $(\gamma-\mathrm{EC})_{n} \mathrm{G}$ binding is consistent with the findings of $\mathrm{Li}$ (1980). In the absence of alternate hypotheses, it is possible that Pavlova lutheri and Tetraselmis maculata, the other 2 species that showed no evidence of $(\gamma-\mathrm{EC})_{n} \mathrm{G}$ biosynthesis may also develop $\mathrm{Cd}$ tolerance through production of a similar, alternate metal-binding compound. Facts arguing against such a unifying hypothesis are the lack of thiol-rich fractions from Sephadex columns of extracts from the latter 2 species, and differences between species in dry weightspecific Cd uptake. Nevertheless, the lack of evidence for $(\gamma-\mathrm{EC})_{n} \mathrm{G}$ production in I. galbana, P. lutheri, and $T$. maculata, coupled with evidence of acquired $\mathrm{Cd}$ tolerance in these species, suggests that other adaptive mechanisms may occur in some microalgae to ameliorate Cd stress.

Acknowledgements. We thank Gail E. Ferris for assistance with algal culturing. N. M. Price provided many helpful comments on the manuscript, which are gratefully acknowledged.

\section{LITERATURE CITED}

Bariaud, A., Maestre, J.-C. (1984). Heavy metal tolerance in a cadmium-resistant population of Euglena gracilis. Bull. environ. Contam. Toxicol. 32: 597-601

Collard, J.-M., Matagne, R. F. (1990). Isolation and genetic analysis of Chlamydomonas reinhardtii strains resistant to cadmium. Appl. environ. Microbiol. 56: 2051-2055

Davies, A. G. (1976). An assessment of the basis of mercury tolerance in Dunaliella tertiolecta. J. mar. biol. Ass. U.K. 56: $39-57$

Delhaize, E., Jackson, P. J., Lujan, L. C., Robinson, N. J. (1989). Poly $(\gamma$-glutamylcysteinyl)glycine synthesis in Datura innoxia and binding with cadmium. Plant Physiol. 89: 700-706

Eaton, A. (1976). Marine geochemistry of cadmium. Mar. Chem. 4: 141-154

Eisler, R. (1985). Cadmium hazards to fish, wildlife, and invertebrates: a synoptic review. Fish and Wildlife Service, U.S. Department of Interior, Contaminant Hazard Reviews, Report No. 2

Ellman, G. L. (1959). Tissue sulfhydryl groups. Arch. Biochem. Biophys. 82: 70-77

Fisher, N. S., Bohe, M., Teyssie, J.-L. (1984). Accumulation and toxicity of $\mathrm{Cd}, \mathrm{Zn}, \mathrm{Ag}$, and $\mathrm{Hg}$ in four marine phytoplankters. Mar. Ecol. Prog. Ser. 18: 201-213

Frithsen, J. B., Oviatt, C. A., Keller, A. A. (1987). A comparison of ecosystem and single-species tests of sewage effluent toxicity. A mesocosm experiment data report. MERL Series, Report No. 7, University of Rhode Island, Kingston, RI

Gekeler, W., Grill, E., Winnacker, E.-L., Zenk, M. H. (1988). Algae sequester heavy metals via synthesis of phytochelatin complexes. Arch. Microbiol. 150: 197-202

Gingrich, D. J., Petering, D. H., Shaw, C. F. III (1984). Zinc and cadmium metabolism in Euglena gracilis: metal distribution in normal and zinc-deficient cells. Mar. environ. Res. 14: 89-102

Grill, E., Winnaker, E.-L., Zenk, M. H. (1985). Phytochelatins: the principal heavy-metal complexing polypeptides of higher plants. Science 230: 574-576

Hall, R. A., Zook, E. G., Meaburn, G. M. (1976). National Marine Fisheries Service survey of trace elements in the fishery resources. NOAA, NMFS, Southeast Fisheries Center, College Park, MD 20740, USA

Jackson, P. J., Robinson, N. J., Delhaize, E. (1989). Cd tolerance in plant cells: a comparison of biochemical and molecular properties of tolerant and sensitive cells. In: Hamer, D. H., Winge, D. R. (eds.) Metal ion homeostasis: molecular biology and chemistry. Alan R. Liss, Inc., New York, p. $337-346$

Jennings, J. R. (1979). The effect of cadmium and lead on the growth of two species of marine phytoplankton with particular reference to the development of tolerance. J. Plankton Res. 1: 121-136

Kondo, N., Isobe, M., Imai, K., Goto, T. (1985). Synthesis of metallothionein-like polypeptides cadystin A and B occurring in fission yeast, and their isomers. Agric. biol. Chem. 49: 71-83

$\mathrm{Li}_{i}$ W. K. W. (1980). Cellular accumulation and distribution of cadmium in Isochrysis galbana during growth inhibition and recovery. J. Plankton Res. 2: 283-294

Maita, Y., Kawaguchi, S. (1989). Amino acid composition of cadmium-binding protein induced in marine diatom, Phaeodactylum tricornutum. Bull. environ. Contam. Toxicol. 43: 394-401

Murasugi, A., Wada, C., Hayashi, Y. (1981). Purification and unique properties in UV and CD spectra of Cd-binding peptide 1 from Schizosaccharomyces pombe. Biochem. biophys. Res. Commun. 103: 1021-1028

Murphy, L. S., Guillard, R. R. L., Gavis, J. (1982). Evolution of resistant phytoplankton strains through exposure to marine pollutants. In: Mayer, G. F. (ed.) Ecological stress and the New York Bight: science and management. Estuarine Research Federation, Columbia, SC, p. 401-412 Peterson, H. G., Healey, F. P. (1985). Metal toxicity to algae: a 
highly $\mathrm{pH}$ dependent phenomenon. Can. J. Fish. Aquat. Sci. 41: 974-979

Provasoli, L., McLaughlin, J. J. A., Droop, M. R. (1957). The development of artificial media for marine algae. Arch. Mikrobiol. 25: 392-428

Rachlin, J. W., Jensen, T. E., Warkentine, B. (1983). The growth response of the diatom Navicula incerta to selected concentrations of metals: cadmium, copper, lead and zinc. Bull. Torrey bot. Club 110: 217-223

Rachlin, J. W., Warkentine, B., Jensen, T. E. (1982). The growth responses of Chlorella saccharophila, Navicula incerta and Nitzschia closterium to selected concentrations of cadmium. Bull. Torrey Bot. Club 109: 129-135

Robinson, N. J., Barton, K., Naranjo, C. M., Sillerud, L. O., Trewhella, J., Watt, K., Jackson, P. J. (1987). Characterization of metal-binding polypeptides from cadmium resistant plant cells. In: Kagi, J. H. R., Nordberg, M. (eds.) Abstracts of the Second International Meeting on Metallothionein and Other Low Molecular Weight Metal Binding Proteins. Zurich. Birkhäuser-Verlag, Basel, p. 25

Robinson, N. J., Jackson, P. J. (1986). Metallothionein-like metal complexes in angiosperms: their structure and function. Physiol. Plant. 67: 499-506

Robinson, N. J., Ratliff, R. L., Anderson, P. J., Delhaize, E., Berger, J. M., Jackson, P. J. (1988). Biosynthesis of poly( $\gamma$ glutamylcysteinyl)glycines in cadmium-tolerant Datura innoxia (Mill.) cells. Plant Sci. 56: 197-204

Robinson, N. J. (1989). Algal metallothioneins: secondary metabolites and proteins. J. appl. Phycol. 1: 5-18

This article was presented by $M$. Levandowsky, New York, USA
Stokes, P. M., Maler, T., Riordan, J. R. (1977). A low molecular weight copper-binding protein in a copper tolerant strain of Scenedesmus acutoformis. In: Hemphil, D. D. (ed.) Trace substances in environmental health. University of Missouri Press, Columbia, MO, p. 146-154

Stone, H., Overnell, J. (1985). Non-metallothionein cadmium binding proteins. Comp. Biochem. Physiol. 80 C: 9-14

Sunda, W. G., Engel, D. W., Thuotte, R. M. (1978). Effects of chemical speciation on toxicity of cadmium to grass shrimp, Palaemonetes pugio: importance of free cadmium ion. Environ. Sci Technol. 12: 409-413

US EPA (1979). Status assessment of toxic chemicals: cadmium. U.S. Environmental Protection Agency, Industrial Environmental Research Laboratory, Cincinnati, OH 45268 USA

Weber, D. N., Shaw, C. F., Petering, D. H. (1987). Euglena gracilis cadmium binding protein-II contains sulfide ion. J. biol. Chem. 262: 6962-6964

Weber, D., Shaw, C. F. III, Petering, D. H. (1988). Properties of structure and function of cadmium-binding proteins/peptides from Euglena gracilis. Mar. environ. Res. 24: 159-162

Wikfors, G. H., Ukeles, R. (1982). Growth and adaptation of estuarine unicellular algae in media with excess copper, cadmium or zinc, and effects of metal-contaminated algal food on Crassostrea virginica larvae. Mar. Ecol. Prog. Ser. 7: 191-206

Wolter, K., Rabsch, U., Krischker, P., Davies, A. G. (1984), Influence of low concentrations of cadmium, copper, and zinc on phytoplankton of natural water samples. Mar. Ecol. Prog. Ser. 19: 167-173

Manuscript first received: September 24, 1991

Revised version accepted: December 5, 1991 